\title{
Features of braking of multi-axle vehicles depending on the layout of their axles
}

\author{
Bogomolov V.O. ${ }^{1}$, Klimenko V.I. ${ }^{1}$, Leontiev D.M. ${ }^{1}$, Frolov A.A. ${ }^{1,2}$, \\ Suhomlin O.S. ${ }^{1}$, Kuripka O.V. ${ }^{1}$ \\ ${ }^{1}$ Kharkiv National Automobile and Highway University, Ukraine \\ ${ }^{2}$ National Scientific Center «Hon. Prof. M. S. Bokarius Forensic Science Institute», Ukraine
}

\begin{abstract}
Annotation. Problem. For an hour, in the scientific-methodical recommendations of the ship-experts, it is installed in the scientific-technical literature of the day-to-day parameters of galvanizing of vantage, bug-capable transport equipment, so that it is inaccurate to introduce autotransport equipment for the eastern part to inaccurate zasob_v unique road transport suit. Goal. The value of the function of galvanizing large transport bridges on the basis of the coordinates of the position to the center of the heavy transport, realizable values, which are realized between the tires and the supporting surface, as well as the support for the rear axle of the transport bridges. Methodology. The approaches adopted in the work to solve this goal are based on the theoretical foundations of braking multi-axle vehicles, the scientific provisions of elastic deformations of pneumatic tires of automobile wheels, geometric and weight parameters of a wheeled vehicle. Results. The equations that allow to calculate the value of the braking coefficient of multi-axle vehicles based on the coordinates of the position of the center of gravity, the realized couplings between the tires and the bearing surface, as well as the load distribution between the respective front and rear axles of the vehicle. Rivnyannya is assigned, which allow the positioning of the coordinates to the center of the car of a multi-axle wheeled transport vehicle for both front and rear axles. The calculation schemes of the position of the coordinates of the center of mass for two-axle, three-axle and four-axle with different axle layout are presented in graphical form, which give a general idea of the mass distribution between the front and rear axles of the vehicle. Originality. Presented in a graphical view of the layout of the positioning of the coordinates to the center of the car for a two-axle, three-axle and one axle with a small layout of the bridges, which give a far-reaching display of the space between the front and rear axles of the transport vehicle. Practical value. The results can be recommended by the experts-auto technicians in the development of technical capabilities for the drivers of vantage transport means, uniqueness of the road-transport usability.
\end{abstract}

Key words: multi-axle vehicle, wheeled vehicle, braking rate, pneumatic tire, interaction with the road surface, braking parameters.

\section{Introduction}

The fundamental basis of active safety of the vehicle is its braking properties, and the nature of braking depends on the interaction of the tires of its wheels with the road surface and the coordinates of the center of gravity of the vehicle.

The interaction of a vehicle tire with the road surface in the theory of wheeled vehicles is characterized by adhesion utilization, which is realized in the longitudinal and transverse directions relative to the plane of rotation of the vehicle wheel during tire deformation during its interaction with the road surface.

Obviously, in this case, the braking process of the vehicle is characterized by the magnitude of its deceleration, which in turn depends on the braking rate of vehicle $(z)$ and is determined by mathematical relationship of which depending on the mode of movement of the vehicle:

- braking due to rolling resistance

- braking due to tire sliding less than $100 \%$

- braking due to $100 \%$ tire sliding

\section{Analysis of publications}

The process of braking multi-axle wheeled 
vehicles affects road safety, as they are used on public roads, so the study of the effectiveness of their braking is an urgent task.

From the scientific and technical literature $[1,2]$ it is known that the braking efficiency of the vehicle depends on the amount of deceleration formed during its braking. Vehicle deceleration is not a constant value, as it depends on many factors, and the analysis of theoretical studies $[8,15,16,19]$ to determine the magnitude of deceleration of wheeled vehicles, showed that the deceleration of the vehicle depends not only on the value of adhesion utilization [3 - 7, $9-14,18]$, which is realized between the tire (double tires [17]) and the road surface, the coordinates of the center of gravity of the vehicle relative to its axles [20], as well as the position of the axles relative to each other.

Analysis of the work [20] showed that the concept of determining the deceleration of a multi-axle wheeled vehicle can be implemented on the basis of the calculation method of determining the coordinates of the center of gravity of the vehicle, adhesion utilization between the tires of its wheels and the road surface, and on load distribution the front and rear axles of the multi-axle vehicle in its static state.

\section{Purpose and Tasks}

The goal is to show the possibility of using in the practice of auto technical examinations, method of determining the deceleration of a multi-axle vehicle on the basis of the adhesion utilization of the tires of its wheels and the coordinates of the position of its center of gravity.

Tasks that need to be solved to achieve the goal:

- determination of the adhesion utilization on the basis of elastic deformations of pneumatic tires of vehicle wheels;

- determination of geometrical parameters of the location of the center of gravity and weight parameters of the wheeled vehicle.

\section{Method of determining the braking parameters of a multi-axle vehicle}

It is known that in the mode of braking due to the rolling resistance of the tires, the braking rate of vehicle $(z)$ is almost equal to the coefficient of rolling resistance $\left(z \cong f_{0}\right)$.

In braking due to $100 \%$ tire sliding the braking rate of the vehicle $(z)$ is equal the coefficient of adhesion utilization of the locked wheel (the coefficient of sliding friction) $z \cong f_{\text {Tp }}$.
In the braking due to tire sliding less than $100 \%$ the inequality $z \neq f_{i} \neq f_{\text {тр }}$ is almost always fulfilled, the braking rate of vehicle $(z)$ is determined by the adhesion utilization $\left(f_{i}\right)$ of the respective axles of the vehicle and the geometric location of its center of gravity in the vertical plane relative to the road surface

Analysis of the scientific and technical literature $[2,16]$ showed that the braking rate for each type of vehicle is determined by individual dependencies. Thus, for example, for a two-axle vehicle (Fig. 1) can be used equation (1), which was proposed by V.A. Ilarionov in the work [19].

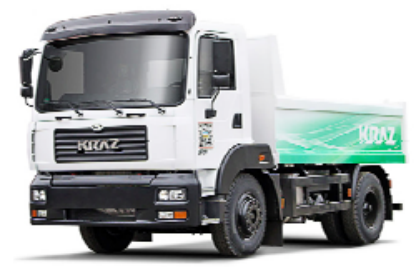

a

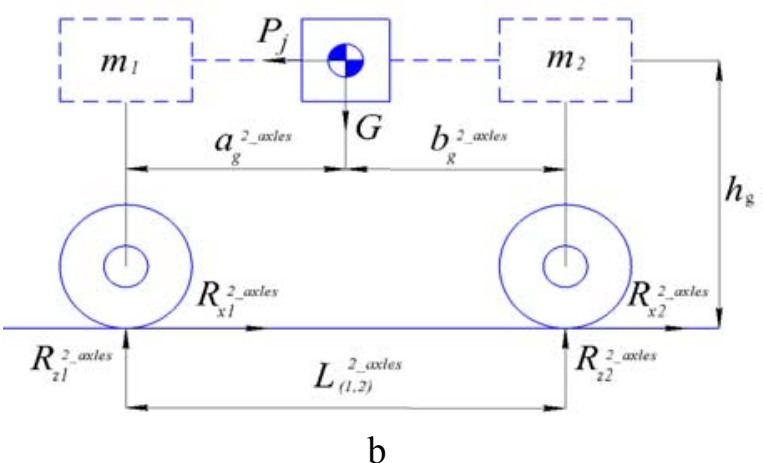

Fig. 1. Distribution of conditional front and rear masses $\left(m_{1}\right.$ and $\left.m_{2}\right)$ two-axle vehicle relative to its center of gravity: a - the appearance of the vehicle [21]; $\mathrm{b}$ - the scheme of distribution of conditional masses; $P_{j}=m \cdot z \cdot g$; $G=m \cdot g ; m=m_{1}+m_{2}$

A similar equation is obtained by other authors in works $[2,16]$.

$$
z=\frac{f_{1} \cdot b_{g}^{2-^{a x l e s}}+f_{2} \cdot a_{g}^{2 \text { axles }}}{L_{(1,2)}^{2 \text { axles }}-h_{g}\left(f_{1}-f_{2}\right)},
$$

where $a_{g}, \quad b_{g}$ and $h_{g}-$ respectively the coordinates of the location of the center of gravity of the wheeled vehicle relative to the front axle, rear axle and the height of the location of the center of gravity above the road surface, $\quad \mathrm{m} ; \quad L_{(1,2)}^{22^{\text {axles }}}=a_{g}^{2-{ }^{2} \text { axles }}+b_{g}^{2{ }^{\text {axxles }}} \quad-$ wheelbase of vehicle, $\mathrm{m}$. 
Coordinates $a_{g}{ }^{2}{ }^{2 a x l e s}$ and $b_{g}{ }^{2}{ }^{2 a x l e s}$ are determined from known dependencies:

$$
\begin{aligned}
& a_{g}^{2 \text { aaxles }}=\frac{L_{(1,2)}^{2 \text { axles }} \cdot R_{z 2}^{2 \text { acxles }}}{m \cdot g} ; \\
& b_{g}^{2 \text { axxles }}=\frac{L_{(1,2)}^{2 \text { axles }} \cdot R_{z 1}^{2 \text { axxles }}}{m \cdot g},
\end{aligned}
$$

where $R_{z}^{2} \overline{1}^{\text {axles }}$ and $R_{z}^{2} \overline{2}^{\text {axles }}$ - respectively vertical loads on the front and rear axles of vehicle, $\mathrm{H} ; m$ - mass of vehicle, $\mathrm{kg} ; g$ - acceleration due to gravity $\mathrm{m} / \mathrm{s}^{2}$.

If a wheeled vehicle has not two but three axles, such as one at the front and two at the rear (Fig. 2), then for such a vehicle, the equation (1) will become a equation (4):

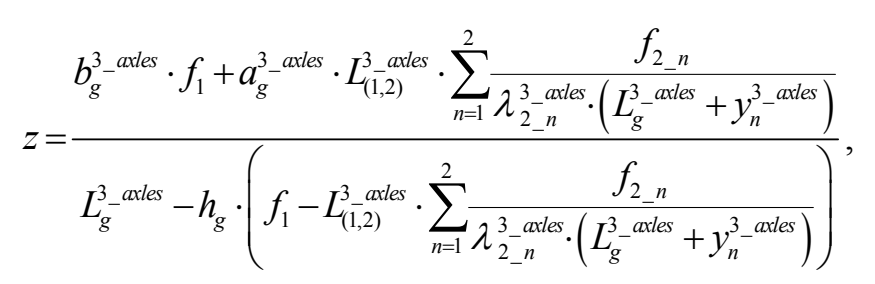

where $a_{g}{ }^{3}$ axles - the coordinate of the location of the center of gravity of the wheeled vehicle relative to its front axle, $\mathrm{m} ; b_{g}{ }^{3}{ }^{\text {axles }}$ - the coordinate of the location of the center of gravity of the wheeled vehicle relative to its conditional rear axle, $m ; L_{g}{ }^{3}$ axles $=a_{g}{ }^{3}$ axles $+b_{g}{ }^{3 \_ \text {axles }}-$ wheelbase of a three- axle vehicle, $\mathrm{m}$.

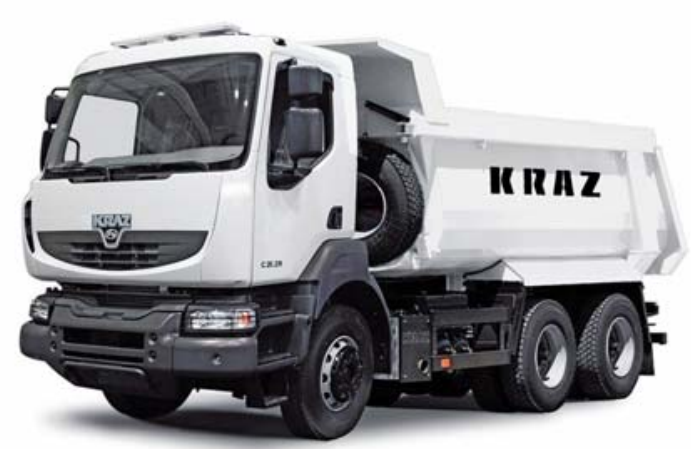

a

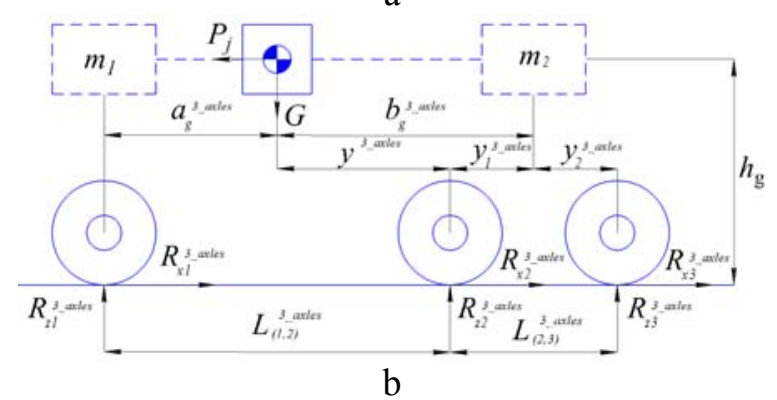

Fig. 2. Distribution of conditional front and rear masses $\left(m_{1}\right.$ and $\left.m_{2}\right)$ three-axle vehicle relative to its center of gravity: a - the appearance of the vehicle [21]; b - the scheme of distribution of conditional masses

Coordinates $a_{g}{ }^{3}{ }^{\text {axles }}$ and $b_{g}{ }^{3 \text { axles }}$ determine from the dependencies:

$$
\begin{aligned}
& a_{g}^{3}{ }^{\text {axles }}=\frac{L_{(1,2)}^{3_{\text {axdes }}} \cdot\left(R_{z 2}^{3} \text { axles }^{\text {ax }}+R_{z 3}^{3} \text { axles }^{\text {ax }}\right)+}{m \cdot g} \rightarrow \\
& \rightarrow \frac{+L_{(2,3)}^{3} \text { axles } \cdot R_{z 3}^{3}{ }^{\text {axdes }}}{m \cdot g} \\
& b_{g}^{3} \text { axtes }=\frac{L_{(1,2)}^{3 \text { axles }} \cdot R_{z 1}^{3 \text { aaxles }}}{m \cdot g}+
\end{aligned}
$$

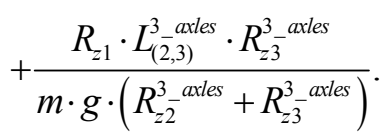

The weight distribution coefficient between the rear axles is determined from the equations, respectively:

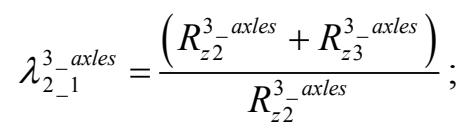

$$
\begin{aligned}
& \lambda_{2_{2}}^{3 \text { _axles }}=\frac{\left(R_{z 2}^{3} \overline{a x l e s}^{3}+R_{z 3}^{3}-^{\text {axles }}\right)}{R_{z \overline{3}}^{3 \text { axles }}} .
\end{aligned}
$$

Longitudinal coordinates $y_{n}{ }^{3}{ }^{3}$ axles the location of axles of three-axle vehicle relative to the coordinates of the center of gravity can be determined using the equations:

$$
\begin{gathered}
y_{1}^{3-a x l e s}=y^{3}-^{\text {axles }}-b_{g}^{3}{ }^{-a x l e s} ; \\
y_{2}^{3} \text {-axles }=L_{(2,3)}^{3} \text { axles }+y^{3 \_a x l e s}-b_{g}^{3} \text { axles }^{\text {ax }} .
\end{gathered}
$$

The value $y^{3 \text {-axles }}$ in equations (9) and (10) we determine from the equation: 


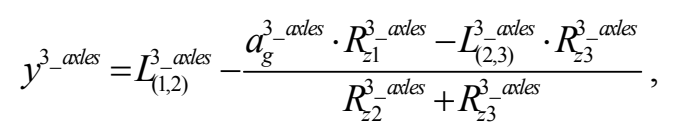

where $R_{z 1}^{3 \_a x l e s}-$ vertical load on the front axle of the vehicle, $\mathrm{N} ; R_{z \overline{2}}^{3 \text { axles }}$ and $R_{z \overline{3}}^{3 \text { axles }}-$ vertical loads on the corresponding rear axles of the vehicle, $\mathrm{N}$.

Similarly, for a four-axle vehicle (Fig. 3), equation (1) is written as equation (12):

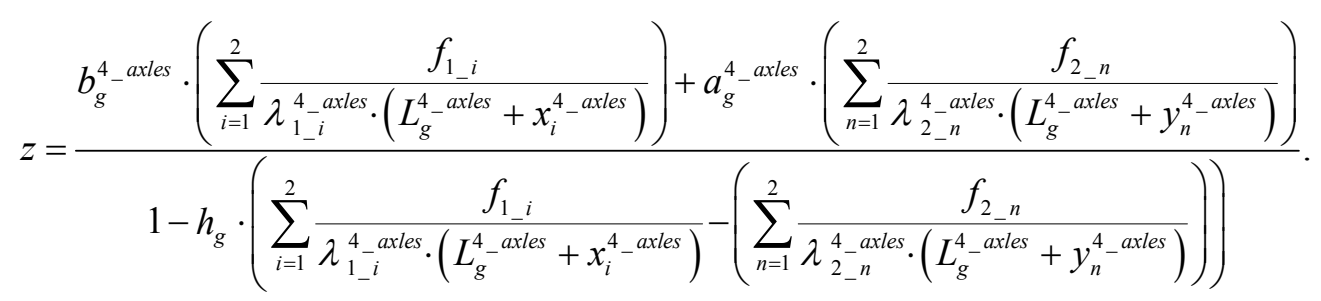

In equation (12) the following notation is accepted: $a_{g}^{4-a x l e s}$ and $b_{g}^{4}$ axles $^{-a}$ - respectively the coordinates of the location of the center of gravity of the wheeled vehicle relative to the conditional front and conditional rear axle of the

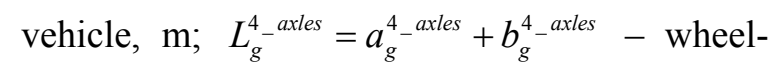
base of a four-axle vehicle, $\mathrm{m}$.

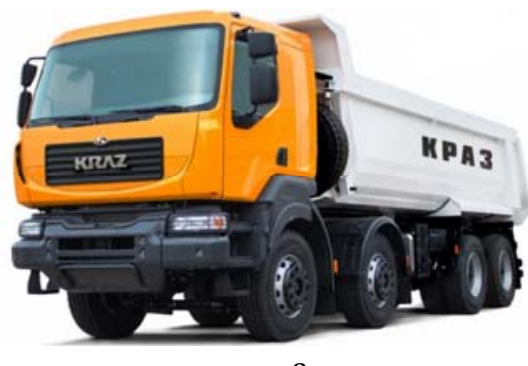

a

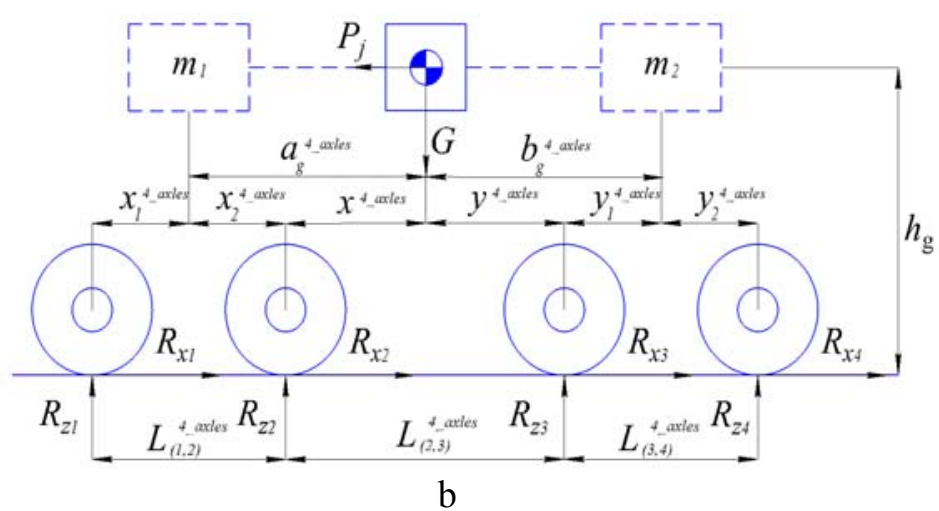

Fig. 3. Distribution of conditional front and rear masses $\left(m_{1}\right.$ and $\left.m_{2}\right)$ four-axle vehicle relative to its center of gravity: $a$ - the appearance of the vehicle [21]; $b$ - the scheme of distribution of conditional masses

Longitudinal coordinates $x_{i}^{4-a x l e s}$ and $y_{n}^{4 \_a x l e s}$ the location of the axles of the four-axle vehicle (in equation (12)), relative to the coordinates of the center of gravity (Fig. 3), can be determined using equations:

$$
\begin{aligned}
& x_{1}^{4 \_a x l e s}=L_{(1,2)}^{4 \_ \text {axles }}+L_{(2,3)}^{4-a x l e s}-y^{4 \_ \text {axles }}-a_{g}^{4-a x l e s} ; \\
& x_{2}^{4} \text { axxles }^{4}=L_{(\overline{2}, 3)}^{4 \text { axles }}-y^{4 \_ \text {axles }}-a_{g}^{4-a x l e s} ;
\end{aligned}
$$

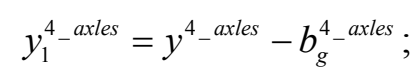

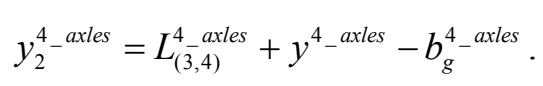

The value of the longitudinal coordinate $y^{4}$-axles , which is included in equations (13) (16) is determined from equation (17):

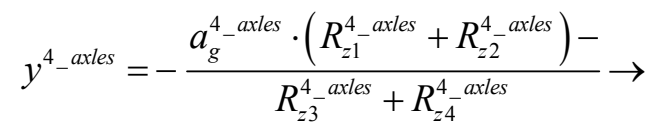

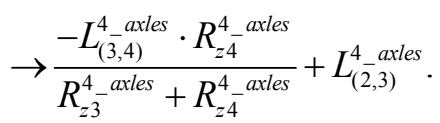

Coordinates $a_{g}{ }^{4}{ }^{4 a x l e s}$ and $b_{g}{ }^{4}{ }^{a x x l e s}$, by analogy with how it was done in equations (2), (3) and (5), (6), we determine from equations (18) and (19):

$$
\begin{aligned}
& a_{g}^{4}-^{\text {axles }}=\frac{L_{-(2,3)}^{4} a^{-a x l e s} \cdot\left(R_{z 3}^{4}-^{\text {axles }}+R_{z 4}^{4} \overline{a x l l e s}^{\text {ax }}\right)+}{m \cdot g} \rightarrow \\
& \rightarrow \frac{+L_{(3,4)}^{4-a x l e s} \cdot R_{z 4}^{4}-\text { axles }}{m \cdot g}+
\end{aligned}
$$

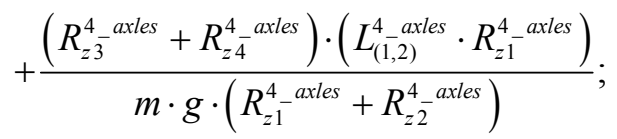




$$
\begin{aligned}
& b_{g}^{4} \text {-axles }=\frac{L_{(2,3)}^{4} \text { axles } \cdot\left(R_{z 1}^{4} \text { axtes }+R_{z 2}^{4} \text { axles }\right)+}{m \cdot g} \rightarrow \\
& \rightarrow \frac{+L_{(1,2)}^{4-a x l e s} \cdot R_{z 1}^{4}-\text { axles }}{m \cdot g}+
\end{aligned}
$$

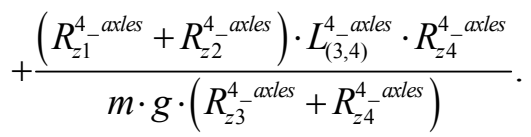

Weight distribution coefficient between the two front $\left(\lambda_{1 \_1}^{4 \_ \text {axles }}\right.$ and $\left.\lambda_{1-2}^{4-a x l e s}\right)$, as well as between the two rear $\left(\lambda_{2}^{4}-1\right.$ axles and $\left.\lambda_{2_{-}^{4}-a x}^{4}\right)$ axes are determined from the corresponding equa-

$$
\begin{aligned}
& \lambda_{1 \_1}^{4} \_^{a x x l e s}=\frac{\left(R_{z 1}^{4} \text { axles }+R_{z 2}^{4} \text { axles }\right)}{R_{z 1}^{4} \text { axles }} ;
\end{aligned}
$$

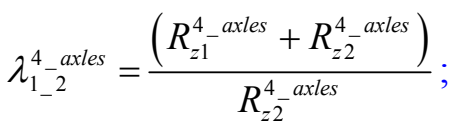

$$
\begin{aligned}
& \lambda_{2 \_1}^{4 \_ \text {axles }}=\frac{\left(R_{z 3}^{4 \_a x l e s}+R_{z \overline{4}}^{4} a^{\text {axles }}\right)}{R_{z \overline{3}}^{4} \text { axles }} ;
\end{aligned}
$$

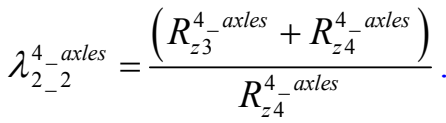
tions $(20)-(23)$ :

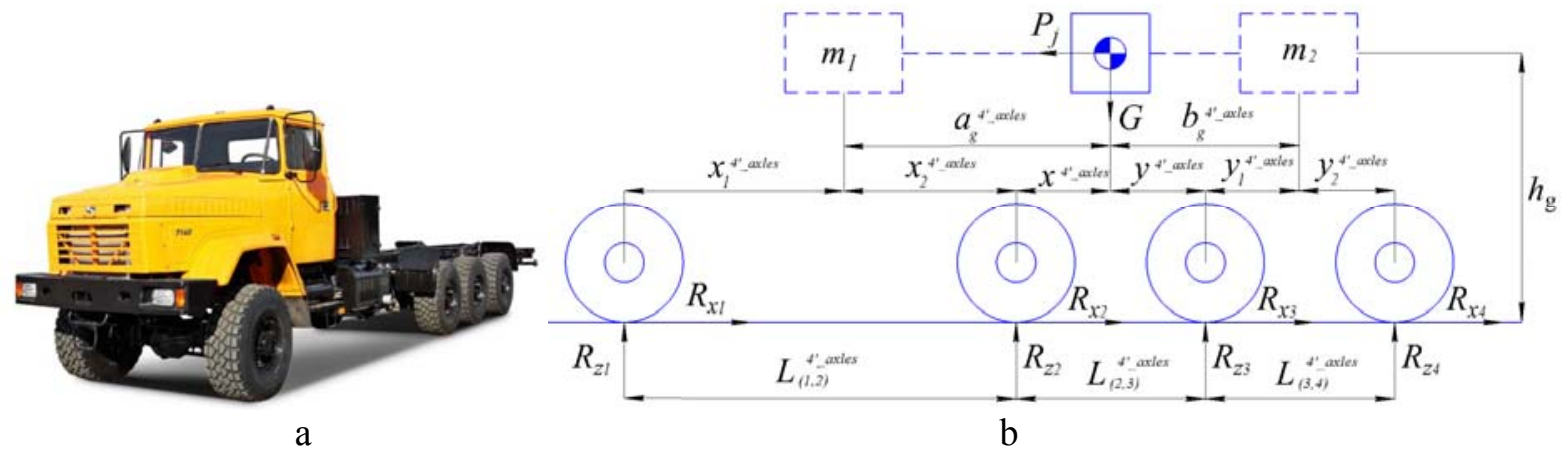

Fig. 4. Distribution of conditional front and rear masses $\left(m_{1}\right.$ and $\left.m_{2}\right)$ four-axle vehicle relative to its center of gravity: $a$ - the appearance of the vehicle [21]; $b$ - the scheme of distribution of conditional masses

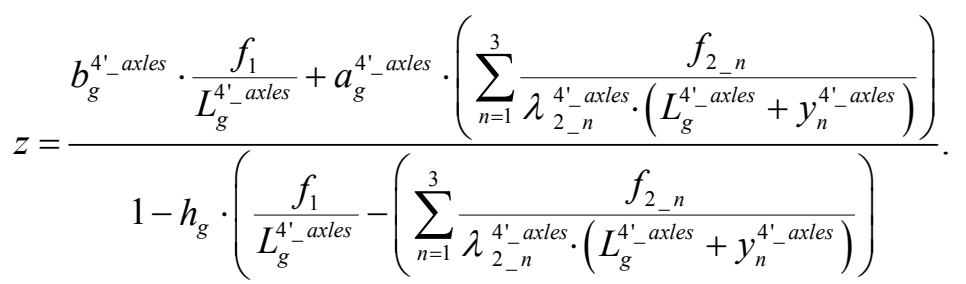

Similarly, for a four-axis vehicle with a another arrangement of axes (Fig. 4), equation (1) can be rewritten as equation (24).

In equation (24) the notation is accepted: $a_{g}^{4 \text { '-axles }}$ and $b_{g}^{4 \text { '-axles }}-$ respectively the coordinates of the location of the center of gravity of the four-axle vehicle relative to the conditional front and conditional rear axle of the vehicle, $\quad \mathrm{m} ; \quad L_{g}^{4{ }^{\prime} \text { axles }}=a_{g}^{4-\text { axles }}+b_{g}^{4{ }^{\prime} \text { axles }} \quad-$ wheelbase of a four-axle vehicle, $m$.

Longitudinal coordinate $y_{i}^{4^{\prime}-\text { axles }}$ the location of the axes of the four-axis vehicle, relative to the coordinates of its center of gravity (Fig. 4), can be determined using the equation:

$$
\begin{aligned}
& y_{1}^{4^{\prime}-\text { axles }}=y^{4^{\prime} \_ \text {axles }}-b_{g}^{4^{\prime} \text {-axles }} \text {; } \\
& y_{2}^{4{ }^{\prime}-\text { axles }}=L_{(2,3)}^{4{ }^{\prime} \text { axles }}+y^{4{ }^{\prime} \_ \text {axles }}-b_{g}^{4{ }^{\prime} \text {-axles }} ; \\
& y_{3}^{4^{\prime} \text {-axles }}=L_{(2,3)}^{4^{\prime} \text { axles }}+L_{(3,4)}^{4 \text { axles }^{2}}+ \\
& +y^{4 \text { __axles }}-b_{g}^{4 \text { '_axles }} \text {. }
\end{aligned}
$$

The value $y^{4}$-axles , which is included in equations (25) - (27) is determined from equation (28).

Coordinates $a_{g}^{4 '-a x l e s}$ and $b_{g}{ }^{4}{ }^{\prime}$ axles , determine from equation (29) and (30), respectively: 


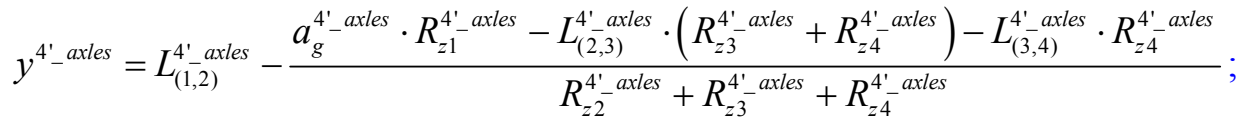

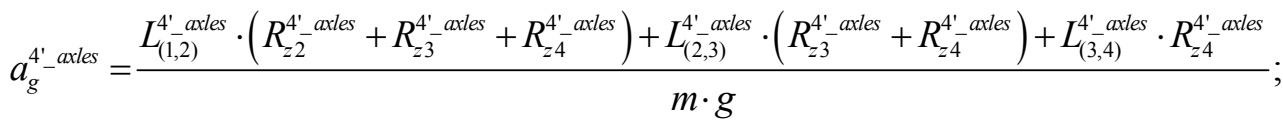

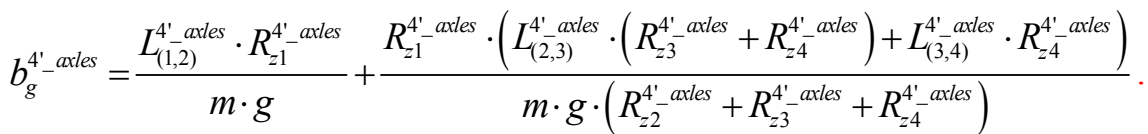

Weight distribution coefficient $\lambda_{2}^{4{ }_{2} \text { axles }}$, $\lambda_{2-2}^{4{ }_{-}^{\prime} \text { axles }}$ and $\lambda_{2-3}^{4{ }_{-} \text {axles }}$, between the three rear axles of the vehicle is determined from the corresponding equations:

$$
\begin{aligned}
& \lambda_{2 \_1}^{4{ }_{-} \text {axles }}=\frac{\left(R_{z 2}^{4{ }^{\prime} \text { axles }}+R_{z 3}^{4{ }^{\prime} \text { axles }}+R_{z 4}^{4{ }^{\prime} \text { axles }}\right)}{R_{z 2}^{4_{-}^{\prime} \text { axles }}} ;
\end{aligned}
$$

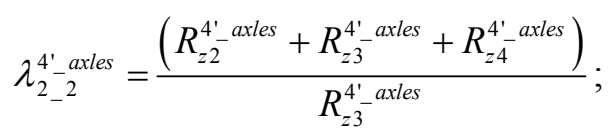

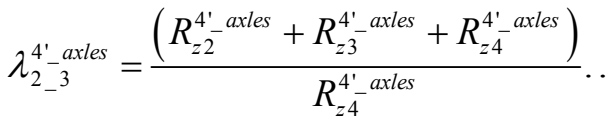

The initial data for calculating the braking efficiency of the considered wheeled vehicles are given in Table 1 and Table 2, and the results of calculating their braking efficiency, including in the event of failure of the brake control elements of the respective brake circuits of the vehicle, are summarized in Table 3.
In Table 4 shows the values of the adhesion utilization between the tires of the respective wheeled vehicles, the braking rate of which is given in Table 3.

As the study showed in [22], the adhesion utilized $\left(f_{i}\right)$ between the tires of the vehicle wheels and the road surface can be determined using the equation (34).

In equation (34) the notation is accepted: $C_{x}-$ torsional stiffness of a pneumatic tire, $\mathrm{N} \cdot \mathrm{m} / \mathrm{rad}[2, \quad 20]$; $\varphi_{x b}-$ coefficient of friction-sliding (adhesion) of a tire of a locked wheel on a road surface; $V_{k}-$ wheel speed, $\mathrm{km} / \mathrm{h}$ [20]; $B_{1}-$ coefficient that takes into account the peculiarities of wheel tire twin [17]; $i_{n}-$ the number of wheels that are installed next to each other [17]; $R_{z i}$ - vertical load on the wheel, N.

It should be noted that in the study [12] it is noted that when using wheel tire twin, the value of the adhesion utilized is reduced due to the reduction of the angles of twist of the tire relative to the road surface.

$$
f_{i}=\frac{C_{x} \cdot \varphi_{x b} \cdot\left(4.625-4.29 \cdot \exp \left(0.0005 \cdot V_{k}\right)\right) \cdot \exp \left(B_{1} \cdot\left(i_{n}-1\right)\right)}{R_{z i}} .
$$

\begin{tabular}{|c|c|c|c|c|c|c|c|c|c|}
\hline № & $\begin{array}{l}\text { The vehicle } \\
\text { (model) }\end{array}$ & $\begin{array}{c}\text { Position of axles on } \\
\text { the vehicle }\end{array}$ & $\begin{array}{l}\text { Total } \\
\text { weight of } \\
\text { vehicle, } \\
(\mathrm{kg})\end{array}$ & $\begin{array}{r}\text { The d } \\
\text { betw } \\
\text { axes } \\
\text { ve } \\
\text { deper } \\
\text { modi } \\
1\end{array}$ & $\begin{array}{l}\text { erence } \\
\mathrm{n} \text { the } \\
\mathrm{f} \text { the } \\
\text { cle } \\
\text { ing on } \\
\text { ation, } \\
\text { n }\end{array}$ & $\begin{array}{c}P_{z l}, \\
\mathrm{~kg}\end{array}$ & $P_{z 2}, \mathrm{~kg}$ & $P_{z 3}, \mathrm{~kg}$ & $\begin{array}{l}P_{z 4}, \\
\mathrm{~kg}\end{array}$ \\
\hline 1 & 2 & 3 & 4 & 5 & 6 & 7 & 8 & 9 & 10 \\
\hline \multirow{2}{*}{1} & \multirow{2}{*}{ Volvo LNG } & \multirow{2}{*}{$\begin{array}{c}4 \times 2 \text { (the scheme of } \\
\text { its axles is shown in } \\
\text { Fig. 1) }\end{array}$} & \multirow{2}{*}{18600} & \multirow{2}{*}{$L_{(1,2)}$} & 3700 & 7100 & 11500 & --- & --- \\
\hline & & & & & 3800 & 7100 & 11500 & --- & --- \\
\hline
\end{tabular}

Table. 1. Weight parameters of vehicles for different distances between his axles 
Continuation of the table. 1

\begin{tabular}{|c|c|c|c|c|c|c|c|c|c|}
\hline 1 & 2 & 3 & 4 & 5 & 6 & 7 & 8 & 9 & 10 \\
\hline 2 & ZiL 4331 & $\begin{array}{l}4 \times 2 \text { (the scheme of } \\
\text { its axles is shown } \\
\text { in Fig. 1) }\end{array}$ & 12000 & $L_{(1,2)}$ & 3300 & 4000 & 8000 & --- & --- \\
\hline \multirow{4}{*}{3} & \multirow{4}{*}{$\begin{array}{c}\text { Volvo FM } 13 \\
\text { T3CB }\end{array}$} & \multirow{4}{*}{$\begin{array}{l}6 \times 2 \text { (the scheme of } \\
\text { its axles is shown } \\
\text { in Fig. 2) }\end{array}$} & \multirow{4}{*}{26000} & \multirow{4}{*}{$L_{(1,2)}$} & 3000 & 8000 & 9500 & 9500 & --- \\
\hline & & & & & 3200 & 8000 & 9500 & 9500 & --- \\
\hline & & & & & 3400 & 8000 & 9500 & 9500 & --- \\
\hline & & & & & 3900 & 8000 & 9500 & 9500 & --- \\
\hline \multirow{4}{*}{4} & \multirow{4}{*}{$\begin{array}{l}\text { Volvo FM } 11 \\
\text { TT1HA }\end{array}$} & \multirow{4}{*}{$\begin{array}{l}6 \times 2 \text { (the scheme of } \\
\text { its axles is shown } \\
\text { in Fig. 2) }\end{array}$} & \multirow{4}{*}{26100} & \multirow{4}{*}{$L_{(1,2)}$} & 3000 & 7100 & 7500 & 11500 & --- \\
\hline & & & & & 3200 & 7100 & 7500 & 11500 & --- \\
\hline & & & & & 3400 & 7100 & 7500 & 11500 & --- \\
\hline & & & & & 3900 & 7100 & 7500 & 11500 & --- \\
\hline \multirow[t]{2}{*}{5} & \multirow{2}{*}{$\begin{array}{c}\text { Volvo FM } 13 \\
\text { PT3HA }\end{array}$} & \multirow{2}{*}{$\begin{array}{l}6 \times 2 \text { (the scheme of } \\
\text { its axles is shown } \\
\text { in Fig. 2) }\end{array}$} & \multirow{2}{*}{26100} & \multirow{2}{*}{$L_{(1,2)}$} & 2580 & 7100 & 7500 & 11500 & --- \\
\hline & & & & & 2780 & 7100 & 7500 & 11500 & --- \\
\hline 6 & $\begin{array}{l}\text { KAMAZ } \\
43114-02\end{array}$ & $\begin{array}{l}6 \times 6 \text { (the scheme of } \\
\text { its axles is shown } \\
\text { in Fig. 2) }\end{array}$ & 15420 & $L_{(1,2)}$ & 3690 & 5490 & 4965 & 4965 & --- \\
\hline 7 & $\begin{array}{l}\text { KAMAZ } \\
53215\end{array}$ & $\begin{array}{l}6 \times 4 \text { (the scheme of } \\
\text { its axles is shown } \\
\text { in Fig. } 2 \text { ) }\end{array}$ & 19355 & $L_{(1,2)}$ & 3690 & 4235 & 7560 & 7560 & --- \\
\hline \multirow{3}{*}{8} & \multirow{3}{*}{$\begin{array}{l}\text { Volvo FM } 11 \\
\text { PT1LA }\end{array}$} & \multirow{3}{*}{$\begin{array}{l}6 \times 2 \text { (the scheme of } \\
\text { its axles is shown } \\
\text { in Fig. 2)* } \\
\text { *the radius of the } \\
\text { wheels of the sec- } \\
\text { ond axle is less } \\
\text { than the radius of } \\
\text { the wheels of the } \\
\text { third axle }\end{array}$} & \multirow{3}{*}{23100} & \multirow{3}{*}{$L_{(1,2)}$} & 2780 & 7100 & 4500 & 11500 & --- \\
\hline & & & & & & & & & \\
\hline & & & & & 2980 & 7100 & 4500 & 11500 & --- \\
\hline \multirow{7}{*}{9} & \multirow{7}{*}{$\begin{array}{c}\text { Volvo FM } 13 \\
\text { Rigid - Tag } \\
\text { Tridem }\end{array}$} & \multirow{7}{*}{$\begin{array}{l}8 \times 4 \text { (the scheme of } \\
\text { its axles is shown } \\
\text { in Fig. } 4 \text { ) }\end{array}$} & \multirow{7}{*}{32000} & \multirow{7}{*}{$L_{(1,2)}$} & 3700 & 8000 & 8660 & 8660 & 6680 \\
\hline & & & & & 3900 & 8140 & 8610 & 8610 & 6640 \\
\hline & & & & & 4100 & 8280 & 8560 & 8560 & 6600 \\
\hline & & & & & 4300 & 8430 & 8510 & 8510 & 6550 \\
\hline & & & & & 4600 & 8570 & 8460 & 8460 & 6510 \\
\hline & & & & & 4900 & 8710 & 8410 & 8410 & 6470 \\
\hline & & & & & 5200 & 8850 & 8360 & 8360 & 6430 \\
\hline \multirow{6}{*}{10} & \multirow{6}{*}{$\begin{array}{l}\text { Volvo FM } 11 \\
\text { Rigid - Pusher } \\
\text { Axle Tridem }\end{array}$} & & & & 2980 & 4350 & 6670 & 8665 & 8665 \\
\hline & & & & & 3280 & 4390 & 6660 & 8650 & 8650 \\
\hline & & $8 \times 4$ (the scheme of & 28250 & $I$ & 3580 & 4420 & 6650 & 8640 & 8640 \\
\hline & & in Fig. 4) & 2030 & $L_{(1,2)}$ & 3780 & 4470 & 6640 & 8620 & 8620 \\
\hline & & & & & 3980 & 4500 & 6630 & 8610 & 8610 \\
\hline & & & & & 4280 & 4550 & 6610 & 8595 & 8595 \\
\hline & & & & & 3105 & 6497 & 6503 & 9500 & 9500 \\
\hline 1 & $\begin{array}{l}\text { PoIVo FII I 1 } \\
\text { Platform - }\end{array}$ & $8 \times 4$ (the scheme of & קחק00 & & 3605 & 6372 & 6378 & 9625 & 9625 \\
\hline 11 & Rear Air Sus- & in Fig. 3) & JLVOU & $L_{(2,3)}$ & 4005 & 6247 & 6253 & 9750 & 9750 \\
\hline & & & & & 4405 & 6122 & 6128 & 9875 & 9875 \\
\hline
\end{tabular}


Table. 2. Geometric parameters of the position of axles on vehicles

\begin{tabular}{|c|c|c|c|c|c|}
\hline № & The vehicle (model) & $\begin{array}{l}\text { Position of axles on the } \\
\text { vehicle }\end{array}$ & $L_{(1,2)}, \mathrm{mm}$ & $L_{(2,3)}, \mathrm{mm}$ & $L_{(3,4)}, \mathrm{mm}$ \\
\hline 1 & Volvo LNG & $\begin{array}{l}4 \times 2 \text { (the scheme of its axles } \\
\text { is shown in Fig. 1) }\end{array}$ & $3700-3800$ & --- & --- \\
\hline 2 & ZiL 4331 & $\begin{array}{l}4 \times 2 \text { (the scheme of its axles } \\
\text { is shown in Fig. 1) }\end{array}$ & 3300 & --- & --- \\
\hline 3 & Volvo FM 13 T3CB & $\begin{array}{l}6 \times 2 \text { (the scheme of its axles } \\
\text { is shown in Fig. 2) }\end{array}$ & $3000-3900$ & 1370 & --- \\
\hline 4 & Volvo FM 11 TT1HA & $\begin{array}{l}6 \times 2 \text { (the scheme of its axles } \\
\text { is shown in Fig. 2) }\end{array}$ & $3000-3900$ & 1370 & --- \\
\hline 5 & Volvo FM 13 РТ3НA & $\begin{array}{l}6 \times 2 \text { (the scheme of its axles } \\
\text { is shown in Fig. 2) }\end{array}$ & $2580-2780$ & 1320 & --- \\
\hline 6 & KAMAZ 43114-02 & $\begin{array}{l}6 \times 6 \text { (the scheme of its axles } \\
\text { is shown in Fig. 2) }\end{array}$ & 3690 & 1320 & --- \\
\hline 7 & KAMAZ 53215 & $\begin{array}{l}6 \times 4 \text { (the scheme of its axles } \\
\text { is shown in Fig. 2) }\end{array}$ & 3690 & 1320 & --- \\
\hline 8 & Volvo FM 11 PT1LA & $\begin{array}{l}6 \times 2 \text { (the scheme of its axles } \\
\text { is shown in Fig. } 2 \text { )* } \\
\text { *the radius of the wheels of } \\
\text { the second axle is less than } \\
\text { the radius of the wheels of } \\
\text { the third axle }\end{array}$ & $2780-2980$ & 1020 & --- \\
\hline 9 & $\begin{array}{c}\text { Volvo FM } 13 \\
\text { Rigid - Tag Tridem }\end{array}$ & $\begin{array}{l}8 \times 4 \text { (the scheme of its axles } \\
\text { is shown in Fig. 4) }\end{array}$ & $3700-5200$ & 1370 & 1380 \\
\hline 10 & $\begin{array}{l}\text { Volvo FM } 11 \\
\text { Rigid - Pusher } \\
\text { Axle Tridem }\end{array}$ & $\begin{array}{l}8 \times 4 \text { (the scheme of its axles } \\
\text { is shown in Fig. } 4 \text { ) }\end{array}$ & $2980-4280$ & 1320 & 1370 \\
\hline 11 & $\begin{array}{c}\text { Volvo FM } 11 \text { Plat- } \\
\text { form - } \\
\text { Rear Air Suspension }\end{array}$ & $\begin{array}{l}8 \times 4 \text { (the scheme of its axles } \\
\text { is shown in Fig. 3) }\end{array}$ & 1995 & $3105-4405$ & 1370 \\
\hline
\end{tabular}

Table. 3. Results of calculations of braking rate of vehicles

\begin{tabular}{|c|c|c|c|c|c|c|c|c|}
\hline & & & & & & & & \\
\hline № & $\begin{array}{l}\text { The vehicle } \\
\text { (model) }\end{array}$ & $\begin{array}{r}\text { The d } \\
\text { betw } \\
\text { axe } \\
\text { ve } \\
\text { depe } \\
\text { modi }\end{array}$ & $\begin{array}{l}\text { ference } \\
\text { of the } \\
\text { icle } \\
\text { ding on } \\
\text { ts } \\
\text { cation, } \\
\text { m }\end{array}$ & 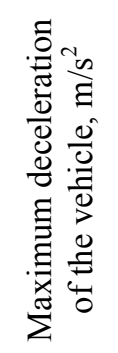 & 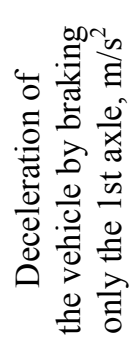 & 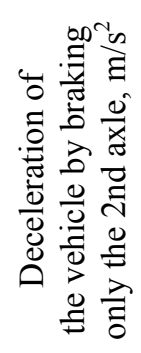 & 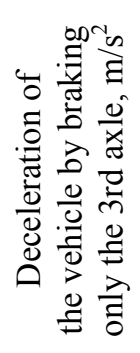 & 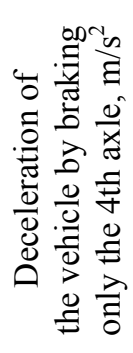 \\
\hline 1 & 2 & & 3 & 4 & 5 & 6 & 7 & 8 \\
\hline 1 & & & 3700 & 5.0112 & 3.4061 & 1.6642 & --- & --- \\
\hline 1 & VOIVO LNG & $L_{(1,2)}$ & 3800 & 5.0177 & 3.4167 & 1.6604 & --- & --- \\
\hline 2 & ZiL 4331 & $L_{(1,2)}$ & 3300 & 6.6120 & 4.3747 & 2.1917 & --- & --- \\
\hline & & & 3000 & 5.5565 & 1.1243 & 2.8218 & 2.0259 & --- \\
\hline 3 & Volvo FM 13 & & 3200 & 5.5657 & 1.1198 & 2.8050 & 2.0465 & --- \\
\hline 5 & T3CB & $L_{(1,2)}$ & 3400 & 5.5746 & 1.1156 & 2.7901 & 2.0657 & --- \\
\hline & & & 3900 & 5.5952 & 1.1071 & 2.7589 & 2.1073 & --- \\
\hline & & & 3000 & 4.9826 & 1.1014 & 1.9563 & 2.2462 & --- \\
\hline 4 & Volvo FM 11 & & 3200 & 4.9848 & 1.0970 & 1.9377 & 2.2653 & --- \\
\hline 4 & TT1HA & $L_{(1,2)}$ & 3400 & 4.9872 & 1.0930 & 1.9211 & 2.2830 & --- \\
\hline & & & 3900 & 4.9940 & 1.0846 & 1.8868 & 2.3215 & --- \\
\hline
\end{tabular}


Continuation of the table. 3

\begin{tabular}{|c|c|c|c|c|c|c|c|c|}
\hline 1 & 2 & & 3 & 4 & 5 & 6 & 7 & 8 \\
\hline \multirow{2}{*}{5} & \multirow{2}{*}{$\begin{array}{c}\text { Volvo FM } 13 \\
\text { PT3HA }\end{array}$} & \multirow{2}{*}{$L_{(1,2)}$} & 2580 & 4.9698 & 1.1133 & 1.9874 & 2.2061 & --- \\
\hline & & & 2780 & 4.9718 & 1.1075 & 1.9640 & 2.2291 & --- \\
\hline 6 & KAMAZ 43114-02 & $L_{(1,2)}$ & 3690 & 5.8098 & 1.8307 & 2.4687 & 1.8816 & $\begin{array}{ll}-- \\
\end{array}$ \\
\hline 7 & KAMAZ 53215 & $L_{(1,2)}$ & 3690 & 6.9423 & 1.2002 & 3.4532 & 2.628 & $\begin{array}{ll}-- \\
\end{array}$ \\
\hline \multirow{2}{*}{8} & \multirow{2}{*}{$\begin{array}{c}\text { Volvo FM } 11 \\
\text { PT1LA }\end{array}$} & \multirow{2}{*}{$L_{(1,2)}$} & 2780 & 5.4229 & 1.2874 & 1.9784 & 2.549 & --- \\
\hline & & & 2980 & 5.4302 & 1.2812 & 1.9603 & 2.5693 & --- \\
\hline \multirow{7}{*}{9} & \multirow{7}{*}{$\begin{array}{l}\text { Volvo FM } 13 \\
\text { Rigid - Tag } \\
\text { Tridem }\end{array}$} & \multirow{7}{*}{$L_{(1,2)}$} & 3700 & 5.3998 & 0.8364 & 2.377 & 1.7901 & 0.9358 \\
\hline & & & 3900 & 5.3870 & 0.8417 & 2.3479 & 1.7897 & 0.9418 \\
\hline & & & 4100 & 5.3753 & 0.8472 & 2.3209 & 1.7889 & 0.9472 \\
\hline & & & 4300 & 5.3642 & 0.8534 & 2.2957 & 1.7878 & 0.9519 \\
\hline & & & 4600 & 5.3530 & 0.8581 & 2.2644 & 1.7881 & 0.9596 \\
\hline & & & 4900 & 5.3431 & 0.8630 & 2.2363 & 1.7881 & 0.9664 \\
\hline & & & 5200 & 5.3345 & 0.8681 & 2.2109 & 1.7877 & 0.9727 \\
\hline \multirow{6}{*}{10} & \multirow{6}{*}{$\begin{array}{l}\text { Volvo FM } 11 \\
\text { Rigid - Pusher } \\
\text { Axle Tridem }\end{array}$} & \multirow{6}{*}{$L_{(1,2)}$} & 2980 & 5.7862 & 0.7054 & 1.8624 & 2.0931 & 1.6331 \\
\hline & & & 3280 & 5.7729 & 0.7051 & 1.8150 & 2.0930 & 1.6552 \\
\hline & & & 3580 & 5.7639 & 0.7043 & 1.7751 & 2.0935 & 1.6757 \\
\hline & & & 3780 & 5.7579 & 0.7067 & 1.7513 & 2.0923 & 1.6873 \\
\hline & & & 3980 & 5.7543 & 0.7076 & 1.7303 & 2.0919 & 1.6987 \\
\hline & & & 4280 & 5.7504 & 0.7094 & 1.7020 & 2.0917 & 1.7149 \\
\hline \multirow{4}{*}{11} & \multirow{4}{*}{$\begin{array}{l}\text { Volvo FM } 11 \\
\text { Platform - Rear } \\
\text { Air Suspension }\end{array}$} & \multirow{4}{*}{$L_{(2,3)}$} & 3105 & 5.2711 & 0.7664 & 1.1206 & 2.1563 & 1.6695 \\
\hline & & & 3605 & 5.2725 & 0.7681 & 1.0807 & 2.1479 & 1.7018 \\
\hline & & & 4005 & 5.2764 & 0.7668 & 1.0516 & 2.1457 & 1.7267 \\
\hline & & & 4405 & 5.2807 & 0.7646 & 1.0256 & 2.1451 & 1.7500 \\
\hline
\end{tabular}

Table. 4. The results of calculations of the maximum possible value of the adhesion utilized between the corresponding tires of the vehicle axles and the road surface

\begin{tabular}{|c|c|c|c|c|c|c|c|}
\hline № & The vehicle (model) & \multicolumn{2}{|c|}{$\begin{array}{c}\text { The difference } \\
\text { between the axes of } \\
\text { the vehicle } \\
\text { depending on its } \\
\text { modification, mm }\end{array}$} & 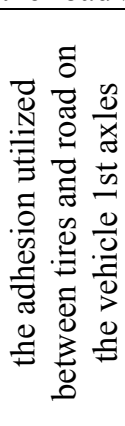 & 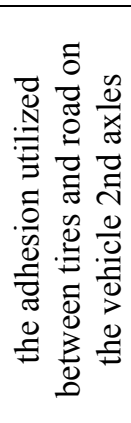 & 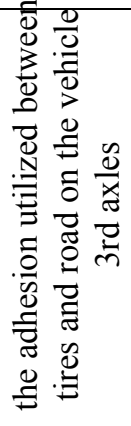 & 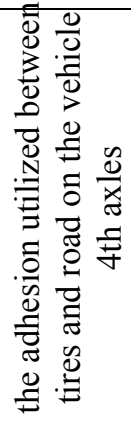 \\
\hline 1 & 2 & \multicolumn{2}{|c|}{3} & 4 & 5 & 6 & 7 \\
\hline \multirow{2}{*}{1} & \multirow{2}{*}{ Volvo LNG } & \multirow{2}{*}{$L_{(1,2)}$} & 3700 & 0.3888 & 0.6291 & --- & --- \\
\hline & & & 3800 & 0.3888 & 0.6291 & $\begin{array}{ll}--- \\
\end{array}$ & --- \\
\hline 2 & ЗиЛ 4331 & $L_{(1,2)}$ & 3300 & 0.5576 & 0.7889 & --- & --- \\
\hline \multirow{4}{*}{3} & \multirow{4}{*}{ Volvo FM 13 T3CB } & \multirow{4}{*}{$L_{(1,2)}$} & 3000 & 0.3306 & 0.7112 & 0.7112 & --- \\
\hline & & & 3200 & 0.3306 & 0.7112 & 0.7112 & --- \\
\hline & & & 3400 & 0.3306 & 0.7112 & 0.7112 & $\begin{array}{ll}-- \\
\end{array}$ \\
\hline & & & 3900 & 0.3306 & 0.7112 & 0.7112 & --- \\
\hline \multirow{4}{*}{4} & \multirow{4}{*}{ Volvo FM 11 TT1HA } & \multirow{4}{*}{$L_{(1,2)}$} & 3000 & 0.3504 & 0.5532 & 0.6127 & --- \\
\hline & & & 3200 & 0.3504 & 0.5532 & 0.6127 & --- \\
\hline & & & 3400 & 0.3504 & 0.5532 & 0.6127 & --- \\
\hline & & & 3900 & 0.3504 & 0.5532 & 0.6127 & --- \\
\hline \multirow{2}{*}{5} & \multirow{2}{*}{ Volvo FM 13 PT3HA } & \multirow{2}{*}{$L_{(1,2)}$} & 2580 & 0.3504 & 0.5532 & 0.6127 & $\begin{array}{ll}-- \\
\end{array}$ \\
\hline & & & 2780 & 0.3504 & 0.5532 & 0.6127 & --- \\
\hline 6 & КамАЗ 43114-02 & $L_{(1,2)}$ & 3690 & 0.4589 & 0.6918 & 0.6918 & $\begin{array}{c}-- \\
\end{array}$ \\
\hline 7 & КамАЗ 53215 & $L_{(1,2)}$ & 3690 & 0.4684 & 0.8167 & 0.8167 & --- \\
\hline \multirow{2}{*}{8} & \multirow{2}{*}{ Volvo FM 11 PT1LA } & \multirow{2}{*}{$L_{(1,2)}$} & 2780 & 0.3651 & 0.8365 & 0.6004 & --- \\
\hline & & & 2980 & 0.3651 & 0.8365 & 0.6004 & --- \\
\hline
\end{tabular}


Continuation of the table. 4

\begin{tabular}{|c|c|c|c|c|c|c|c|}
\hline 1 & 2 & & & 4 & 5 & 6 & 7 \\
\hline \multirow{7}{*}{9} & \multirow{7}{*}{$\begin{array}{c}\text { Volvo FM } 13 \text { Rigid - } \\
\text { Tag Tridem }\end{array}$} & \multirow{7}{*}{$L_{(1,2)}$} & 3700 & 0.2881 & 0.6805 & 0.6805 & 0.5396 \\
\hline & & & 3900 & 0.2862 & 0.6829 & 0.6829 & 0.5418 \\
\hline & & & 4100 & 0.2844 & 0.6853 & 0.6853 & 0.5440 \\
\hline & & & 4300 & 0.2825 & 0.6877 & 0.6877 & 0.5469 \\
\hline & & & 4600 & 0.2807 & 0.6902 & 0.6902 & 0.5491 \\
\hline & & & 4900 & 0.2789 & 0.6927 & 0.6927 & 0.5513 \\
\hline & & & 5200 & 0.2772 & 0.6952 & 0.6952 & 0.5536 \\
\hline \multirow{6}{*}{10} & \multirow{6}{*}{$\begin{array}{l}\text { Volvo FM } 11 \text { Rigid - } \\
\text { Pusher Axle Tridem }\end{array}$} & \multirow{6}{*}{$L_{(1,2)}$} & 2980 & 0.3680 & 0.5403 & 0.6802 & 0.6802 \\
\hline & & & 3280 & 0.3671 & 0.5409 & 0.6809 & 0.6809 \\
\hline & & & 3580 & 0.3664 & 0.5414 & 0.6814 & 0.6814 \\
\hline & & & 3780 & 0.3652 & 0.5419 & 0.6824 & 0.6824 \\
\hline & & & 3980 & 0.3646 & 0.5425 & 0.6828 & 0.6828 \\
\hline & & & 4280 & 0.3634 & 0.5437 & 0.6835 & 0.6835 \\
\hline \multirow{4}{*}{11} & \multirow{4}{*}{$\begin{array}{l}\text { Volvo FM } 11 \text { Platform } \\
\text { - Rear Air Suspension }\end{array}$} & \multirow{4}{*}{$L_{(2,3)}$} & 3105 & 0.3912 & 0.3910 & 0.6502 & 0.6502 \\
\hline & & & 3605 & 0.3946 & 0.3944 & 0.6449 & 0.6449 \\
\hline & & & 4005 & 0.3980 & 0.3978 & 0.6397 & 0.6397 \\
\hline & & & 4405 & 0.4014 & 0.4012 & 0.6347 & 0.6347 \\
\hline
\end{tabular}

As initial conditions for calculation it was accepted: initial braking speed - $13.9 \mathrm{~m} / \mathrm{s}$ $(50 \mathrm{~km} / \mathrm{h})$; coefficient of friction-sliding (adhesion) of the tire on the road surface - 0.8 ; coefficient of rolling resistance of the vehicle wheels - 0.012; height of the center of gravity of the vehicle $-0.8 \mathrm{~m}$; wheel radius of the vehicle $-0.5 \mathrm{~m}$ (for Volvo FM 11 PT1LA the radius of the reduced wheel was assumed to be $0.35 \mathrm{~m}$ ); pressure in the tires of the wheels of a vehicle with a single tire - $0.53 \mathrm{MPa}$; pressure in the tires of the wheels of a vehicle with tires twins - $0.5 \mathrm{MPa}$; simplex-type brake mechanisms are installed on all axles; the service brake system of a wheeled vehicle, including a multi-axle vehicle, was equipped with a double circuit line.

From the results of the study it can be seen that the maximum braking rate of the wheeled vehicle increases with increasing distance $L_{(1,2)}$ between the axles of the vehicle (respectively for the car Volvo FM 11 Platform - Rear Air Suspension - the distance $L_{(2,3)}$ between the axles). If we compare the braking rate of twoaxle, three-axle and four-axle wheeled vehicles, we can see that the braking rate of a four-axle vehicle decreases, this is primarily due to the reduction of the adhesion utilized between the respective tires and the road surface (Table 4).

It should be noted that increasing the distance between the respective axles $L_{(1,2)}$ (respectively for the car Volvo FM 11 Platform - Rear Air Suspension - the distance $L_{(2,3)}$ between the axles) leads to a decrease in the braking rate of the vehicle if it brakes on account only the first axis.

If we consider the braking speedrate of the vehicle only due to the second or third axle, then for three-axle vehicles the braking rate due only to the second or third axle will increase. The braking rate of vehicles with more axles, in the case of braking due to only the second or third axle, will decrease. The braking rate of a fouraxle vehicle, in the event of a failure of its braking system, when braking only due to the fourth axle will increase in the direction of increasing the distance between the corresponding axles $L_{(1,2)}$ (respectively for Volvo FM 11 Platform - Rear Air Suspension - distance $L_{(2,3)}$ between the axes). Comparing the braking rate due to the second, third and fourth axles, for a four-axle wheeled vehicle (Fig. 4) it can be argued that their spare braking system is better to implement on the basis of the second and third axles. The study also showed that for a four-axle vehicle (Fig. 3), which has a different arrangement of axles, the implementation of its spare brake system is better to perform on the basis of the third and fourth axles.

From table 4 it can be seen that when determining the braking rate of a multi-axle wheeled vehicle, the maximum value of the adhesion utilized between the respective tires of the vehicle axles and the road surface plays an important role.

The analysis of the results of the calculation of the maximum value of the adhesion utilized of the corresponding axle tires of multi-axle vehicles showed that the wheels twin on the axles reduce the realized clutch by $14 \%$. Wheels twin of the vehicle reduce its braking rate by 8 $10 \%$, but at the same time, allows to increase the load capacity of a multi-axle vehicle by $12 \%$ at a speed moving of multi-axle vehicle no more $13.9 \mathrm{~m} / \mathrm{s}(50 \mathrm{~km} / \mathrm{h})$. 


\section{Conclusion}

Thus, the analysis of theoretical studies to determine the magnitude of the deceleration of the vehicle showed that the deceleration of the vehicle depends not only on the amount of tractionadhesion utilized between the tire (tires twin) and the road surface, but also on the coordinates of the center of gravity of the vehicle and position of its axes.

Theoretical analysis of the braking dynamics of multi-axle vehicles equipped with twin tires showed that the amount of deceleration of such a vehicle in addition to the amount of adhesion utilized between the tire and the road surface, also affects the nature of weight distribution between vehicle axles. Therefore, neglect of the weight and geometric parameters of the vehicle, for example during the study of the circumstances of a traffic accident, can lead to erroneous results and conclusions.

The braking rate of a wheeled vehicle, regardless of the number of axles installed on the vehicle, can be determined by calculation based on the weight distribution of the vehicle between its front and rear axles in the static state of the vehicle, by weighing the respective axes of the vehicle on the weighing system.

The implementation of a secondary (spare) brake system on a multi-axle wheeled vehicle must be performed taking into account the geometric position of the axles of such a car and the nature of the weight distribution between the respective axles of the vehicle.

Tires twin on the corresponding axles of the multi-axle vehicle reduce the braking rate of the vehicle by $8-10 \%$ while increasing the load capacity of the vehicle by $12 \%$ at a speed moving of multi-axle vehicle no more $13.9 \mathrm{~m} / \mathrm{s}$ $(50 \mathrm{~km} / \mathrm{h})$.

\section{Acknowledgement}

This work was conducted under the Scientific research «Improving the survivability of military multi-axle trucks by using an automatic transmission and increasing the reliability of the brakes ", 08-53-21, funded by the Ministry of Education and Science of Ukraine.

\section{Conflict of interests}

The authors declare that there is no conflict of interests regarding the publication of this paper.

\section{References}

1. Pacejka H.B. (2005) Tire and Vehicle Dynamics. SAE.: N SAE0013. $620 \mathrm{p}$.
2. Туренко А., Михалевич Н., Леонтьев Д.и др. (2015) Реализация интеллектуальных функций в электронно-пневматическом тормозном управлении транспортных средств. Монография. Харьков: ХНАДУ. Turenko А., Mikhalyevych N., Leontiev D. \& etc. (2015) Realizatsiya intellektualnyih funktsiy $\mathrm{V}$ elektronno-pnevmaticheskom tormoznom upravlenii transportnyih sredstv [Implementation of intelligence functions in electronic-pneumatic brake control of vehicles]. Kharkov: KhNAHU.

3. (2010) Uniform provisions concerning the approval of vechicles of categories $\mathrm{M}, \mathrm{N}$ and $\mathrm{O}$ with regard to braking: Regulation №13 of the Economic Commission for Europe of the United Nations (UN/ECE). - On condition 30.09.2010. Official Journal of the European Union..

4. O. M. Braun, B. N. Persson, B. Steenwyk, A. Warhadpande (2016) On the dependency of friction on load: Theory and experiment. EPL (Europhysics Letters). 113. 5. 1-5. https://doi.org/10.1209/0295-5075/113/56002

5. Miao Yu, Guoxiong Wu, Lingyun Kong, Yu Tang (2017) Tire-Pavement Friction Characteristics with Elastic Properties of Asphalt Pavements. Applied Sciences. 7. 1-16 https://doi.org/10.3390/ app7111123

6. Manuel Acosta, Stratis Kanarachos, Mike Blundell (2017) Road Friction Virtual Sensing: A Review of Estimation Techniques with Emphasis on Low Excitation Approaches. Applied Sciences. 7. 1-47 https://doi.org/10.3390/app712 1230

7. Jin L-Q, Ling M, Yue W (2017) Tire-road friction estimation and traction control strategy for motorized electric vehicle. PLOS ONE 12(6). P. 118. https://doi.org/10.1371/journal.pone.0179526

8. Ломака С.И., Рыжих Л.О., Леонтьев Д.Н., Чебан А.А., Красюк А.Н. (2009) Системы автоматического регулирования и практическая реализация алгоритма управления их исполнительными механизмами. Вестник национального политехнического университета „ХПИ”, 47. 918 Lomaka S. I., Ryzhih L. A., Leontiev D. N. , CHeban A. A., Krasyuk A. N. (2009) Sistemy avtomaticheskogo regulirovaniya i prakticheskaya realizaciya algoritma upravleniya ih ispolnitel'nymi mekhanizmami [Automatic control systems and practical implementation of the control algorithm]. Vestnik nacional'nogo tekhnicheskogo universiteta «HPI». 47. 9-18.

9. Seyedmeysam KHALEGHIAN, Anahita EMAMI, Saied TAHERI (2017) A technical survey on tireroad friction estimation» Friction 5 (2). 123-146 https://doi.org/10.1007/ s40544-017-0151-0

10. Bin Ma, Hong-guo Xu, Yong Chen, Mu-yi Lin (2017) Evaluating the tire wear quantity and differences based on vehicle and road coupling method. Advances in Mechanical Engineering, 9 (5). 1-13 $\quad$ https://doi.org/10.1177/ $\underline{1687814017700063}$ 
11. Ise T., Higuchi M., Suzuki Y., Tachiya H. (2017) Measurement on Friction Coefficients of Tire Grounding Surface in Arbitrary Directions under High-Load. Experimental mechanics. 57. 9. 13831393 https://doi.org/ 10.1007/ s11340-017-0309-8

12. Akutagawa K. (2017) Technology for Reducing Tire Rolling Resistance. Tribology online. 12. 3. 99-102 https://doi.org/10.2474/trol.12.99

13. Renski A. (2017) Analysis of the Influence of the Drive Force Distribution Between Axles on an Automobile Stability in Its Curvilinear Motion. Conat 2016: International Congress of Automotive and Transport Engineering. 55-63 https://doi.org/10.1007/978-3-319-45447-4 6

14. Grinchuk P.S., Shnip A.I. (2016) On a thermodynamic mechanism of dissipation of mechanical energy in porous elastomers as applied to the problem of heating of automobile tires. Journal of Engineering Physics and Thermophysics, 89. 6. 1358-1364 https://doi.org/ 10.1007/ s10891-016-1501-x

15. Леонтьев Д.Н. (2010) Усовершенствованный алгоритм управления АБС // Автомобильная промышленность. №9. C 25-28. Leontiev D. N. (2010) Usovershenstvovannyiy algoritm upravleniya ABS [Advanced algorithm for controlling ABS] // Avtomobilnaya promyishlennost. 9. 25-28.

16. Леонтьев Д.Н., Туренко А.Н., Богомолов В.А. (2016) Способ определения замедления многоосного автомобиля на основе реализуемых сцеплений его колес и расположения координат центра масс. Вісник Харківського національного автомобільнодорожнього університету. 75, 13-17. Leontiev D. N., Turenko A. N., Bogomolov V. A. (2016) Sposob opredeleniya zamedleniya mnogoosnogo avtomobilya na osnove realizuemyih stsepleniy ego koles i raspolozheniya koordinatyi tsentra mass [The method for determining the deceleration of a multi-axle vehicle on the basis of realized adhesions of its wheels and the location of the coordinate of the center of mass] Vestnik Harkovskogo natsionalnogo avtomobilnodorozhnogo universiteta. 75, 13-17.

17. Leontiev D., Don E. (2016) Specifics of automobile dual wheels interaction with the supporting surface. Автомобильний транспорт, 39. 74 - 79. Leontiev D., Don E. (2016) Specifics of automobile dual wheels interaction with the supporting surface. Automobile Transport, 39. 74 $-79$

18. Gaojian Cui, Jinglei Dou, Shaosong Li, Xilu Zhao, Xiaohui Lu, and Zhixin Yu (2017) Slip Control of Electric Vehicle Based on Tire-Road Friction Coefficient Estimation. Mathematical Problems in Engineering. Hindawi. 2017. 1-8 https://doi.org/10.1155/2017/3035124

19. Иларионов В.А., Пчелин И.К. (1975) Анализ тормозной динамичности автобуса. Труды ВСЕИавтобуспрома. 95-110. Ilarionov V. A.,
Pchelin I. K. (1975) Analiz tormoznoy dinamichnosti avtobusa [Analysis of the braking dynamics of the bus]. Trudyi VKEIavtobusproma. 95-110.

20. Леонтьєв Д.М. (2021) Теоретичні основи гальмування багатовісних транспортних засобів 3 електропневматичною гальмовою системою. / дис. на здобуття ступеня докт. техн. наук. Леонтьев Дмитро Миколайович // Харків: ХНАДУ. Leontiev D.M. (2021) Teoretychni osnovy halmuvannia bahatovisnykh transportnykh zasobiv $\mathrm{z}$ elektropnevmatychnoiu halmovoiu systemoiu [Theoretical bases of braking of multi-axle vehicles with electropneumatic brake system] / dys. na zdobuttia stupenia dokt. tekhn. nauk. Leontiev Dmytro Mykolaiovych // - Kharkiv : KhNADU.

21. (2013) Catalogue of trucks KRAZ.

22. Леонтьєв Д.М., Махлай С. М. (2018) Визначення зупинного шляху автомобіля, що обладнаний антиблокувальною системою. Вісник Одеського науково-дослідного інституту судових експертиз. 4. 44-50. Leontiev D. M., Makhlai S. M. (2018) Vyznachennia zupynnoho shliakhu avtomobilia, shcho obladnanyi antyblokuvalnoiu systemoiu [Determination of the stopping distance of a vehicle equipped with an anti-lock braking system]. Visnyk Odeskoho naukovo-doslidnoho instytutu sudovoi ekspertyzy. 4, 44-50.

Bogomolov Viktor ${ }^{1}$, DSci (Engineering), Prof., Departament of Automobiles named after A.B. Gredeskul, e-mail: bogomolov.viktor@gmail.com, Phone.: +38050-902-76-00,

ORCID: http://orcid.org/0000-0001-6871-8244

Klimenko Valeriy ${ }^{1}$, DSci (Engineering), Prof., Departament of Automobiles named after A.B. Gredeskul,, e-mail: valeriy.klimenko@gmail.com, Phone.: +38050-845-65-29,

ORCID: http://orcid.org/0000-0002-7399-0397

Leontiev Dmytro ${ }^{1}, \mathrm{PhD}$, Assoc. Prof. Departament of Automobiles named after A. B. Gredeskul, e-mail: dima.a3alij@gmail.com,

Phone.: +38095-903-68-88,

ORCID: http://orcid.org/0000-0003-4255-6317

Frolov Andrii ${ }^{1,2}$, graduate student, researcher, forensic expert National Scientific Center «Hon. Prof. M. S. Bokarius Forensic Science Institute» e-mail: frolov.andrey.5120@gmail.com,

Phone.:+38098-826-21-98,

ORCID: http://orcid.org/0000-0002-3868-4511

Suhomlyn Oleksandr ${ }^{1}$ graduate student, Departament of Automobiles named after A.B. Gredeskul e-mail: suhomlin.alexandr@gmail.com, Phone.:+38099-770-14-28

ORCID: http://orcid.org/0000-0002-2275-6891

Kuripka Oleksandr ${ }^{1}$, graduate student, Assist. Departament of Automobiles named after A.B.Gredeskul, e-mail: kuripkas199721@gmail.com Phone.: +38050-845-65-29

ORCID: http://orcid.org/0000-0002-0550-7201 
${ }^{1}$ Kharkiv National Automobile and Highway University, Yaroslava Mudrogo str., 25, Kharkiv, Ukraine, 61002

${ }^{2}$ National Scientific Center «Hon. Prof. M. S. Bokarius Forensic Science Institute», Zolochivska street, 8A, Kharkiv, Ukraine, 61177

\section{Особливості гальмування багатовісних транспортних засобів в залежності від компановки їх мостів}

Анотація. Проблема. На даний час в науковометодичних рекомендаціях судово-експертних установ та в науково-технічній літературі відсутні універсальні методики щчодо визначення параметрів гальмування вантажних багатовісних транспортних засобів, щзо не дає можливості використовувати типові підходи при складанні висновків авто-технічної експертизи. Мета. Мета полягає в тому, щзоб показати можливість використаннея в практиці проведення автотехнічних експертиз, методики визначення уповільення багатовісного транспортного засобу на основі реалізованих зчеплень шин його коліс та координат положення його иентру тяжіння. Методологія. Прийняті в роботі підходи до вирішення поставленої мети базуються на теоретичних основах гальмування багатовісних транспортних засобів, наукових положень пружних деформацій пневматичних иин автомобільних коліс, геометричних та вагових параметрах колісного транспортного засобу. Результати. Визначено рівняння, які дозволяють розрахувати значення коефіиієнта гальмування багатовісних транспортних засобів на основі координат положення його иентру тяжіння, реалізованих зчеплень між иинами автомобільних коліс та поверхнею дорожнього покриття, а також розподілення навантаження між відповідними передніми $і$ задніми вісями багатовісного транспортного засобу. Визначено рівняння, які дозволяють розрахувати положення координати иентру тяжіння багатовісного колісного транспортного засобу щзодо його передніх $i$ задніх осей. Оригінальність. Результати проведеної роботи дають загальне уявлення про вплив геометричних та вагових параметрів багатовісного транспортного засобу на ефективність його гальмування, в тому числі й при виході з ладу елементів його гальмового керування. Практичне значення. Отримані результати можуть бути рекомендовані експертам-автотехнікам при визначені технічної можливості уникнення дорожньо-транспортної події в умовах виникнення несправностей в гальмовому керуванні транспортного засобу.

Ключові слова: багатовісний транспортний засіб, колісний транспортний засіб, коефічієнт гальмування, пневматична иина, взаємодія з поверхнею дорожнього покриття, параметри гальмування.

Богомолов Віктор Олександрович ${ }^{1}$, д.т.н., проф., професор кафедри автомобілів ім. А. Б. Гредескула, e-mail: bogomolov.viktor@gmail.com, Phone.: +38050-902-76-00,

ORCID: http://orcid.org/0000-0001-6871-8244

Клименко Валерій Іванович ${ }^{1}$, д.т.н., проф., зав. кафедри автомобілів ім. А. Б. Гредескула, e-mail: valeriy.klimenko@gmail.com,

Phone.: +38050-845-65-29,

ORCID: http://orcid.org/0000-0002-7399-0397

Леонтьєв Дмитро Миколайович ${ }^{1}$, к.т.н., доц., доцент кафедри автомобілів ім. А. Б. Гредескула, e-mail: dima.a3alij@gmail.com,

Phone.: +38095-903-68-88,

ORCID: http://orcid.org/0000-0003-4255-6317

Фролов Андрій Анатолійович ${ }^{1,2}$, аспірант, науковий співробітник, судовий експерт ННЦ „Інститут судових експертиз ім. Засл. проф. М. С. Бокаріуса",

e-mail: frolov.andrey.5120@gmail.com,

Phone.:+38098-826-21-98,

ORCID: http://orcid.org/0000-0002-3868-4511

Сухомлин Олександр Вячеславович ${ }^{1}$ аспірант кафедри автомобілів ім. А. Б. Гредескула, e-mail: suhomlin.alexandr@gmail.com, Phone.:+38099-770-14-28

ORCID: http://orcid.org/0000-0002-2275-6891

Куріпка Олександр Володимирович ${ }^{1}$, аспірант, асистент кафедри автомобілів ім. А. Б. Гредескула, e-mail: kuripkas199721@,gmail.com

Phone.: +38050-845-65-29

ORCID: http://orcid.org/0000-0002-0550-7201

${ }^{1}$ Харківський національний автомобільнодорожній університет, 61002, Україна, м. Харків, вул.Ярослава Мудрого, 25.

${ }^{2}$ Національний науковий центр «Інститут судових експертиз ім. Засл. проф. М. С. Бокаріуса», 61177, Україна, м. Харків, вул. Золочівська, 8А 